Dominik Marcinkowski

ORCID: 0000-0002-0177-1486

Uniwersytet Opolski

\title{
Polski rok 1989 w perspektywie czechosłowackich dzienników opiniotwórczych
}

DOI: $10.19195 / 1643-0328.26 .7$

Słowa kluczowe: Czechosłowacja, stosunki polsko-czechosłowackie, rok 1989, „Rudé právo”, „Mláda fronta”

\section{Wprowadzenie}

Rok 1989 to moment przełomu w najnowszej historii państw wchodzących w skład bloku wschodniego ${ }^{1}$. To właśnie wówczas miały miejsce najbardziej spektakularne wydarzenia, które doprowadziły do rozpadu rządów partii komunistycznych. Rok ten był także niezwykle istotny w wypadku Polski i Czechosłowacji. Wtedy to obydwa państwa weszły na drogę reformy systemowej, która w każdym $\mathrm{z}$ nich wyglądała inaczej. W odniesieniu do Polski można uznać, że rok 1989 rozpoczął się od obrad Okrągłego Stołu, a zakończył nowelizacją konstytucji i początkiem wprowadzania planu Leszka Balcerowicza². W Czechosłowacji zaś do wydarzeń, które miały decydujący wpływ na późniejsze zmiany systemowe, doszło dopiero pod koniec roku. W listopadzie wybuchła tak zwana aksamitna rewolucja, która przybrała kształt szybkich zmian politycznych pod naciskiem ulicznych manifestacji. Wydarzenia rozpoczynające demontaż władzy komunistycznej w państwie Czechów i Słowaków trwały jedenaście dni - miały miejsce między 17 a 28 listopada 1989 roku³.

${ }^{1}$ O znaczeniu roku 1989 w historii państw należących do bloku wschodniego zob. P. Kopeček, Rok 1989 ve střední Evropě (Polsko, Mad'arsko, NDR, Československo), [w:] P. Krákora et al., Obnova demokracie $v$ Československu po roce 1989, Praha 2010, s. 218-225.

${ }^{2} \mathrm{Na}$ temat polskich wydarzeń roku 1989 zob. J. Skórzyński, Okrągły Stót. Wynegocjowany koniec PRL, Kraków 2019; A. Dudek, Historia polityczna Polski 1989-2005, Kraków 2007, s. 11-41; idem, Reglamentowana rewolucja: rozkład dyktatury komunistycznej w Polsce 1988-1990, Kraków 2004; K. Trembicka, Okrągty Stół w Polsce. Studium o porozumieniu politycznym, Lublin 2003; A.L. Sowa, Historia polityczna Polski 19441991, Kraków 2011, s. 624-653; A. Paczkowski, Od sfałszowanego zwycięstwa do prawdziwej klęski. Szkice do portretu PRL, Kraków 1999, s. 126-187.

${ }^{3}$ M. Bankowicz, Zlikwidowane państwo. Ze studiów nad polityką Czechosłowacji, Kraków 2003, s. 90-94; A. Burakowski, A. Gubrynowicz, P. Ukielski, 1989 - Jesień Narodów, Warszawa 2009, s. 198-221; J. Toma- 
Niniejszy artykuł został poświęcony problematyce polskich wydarzeń roku 1989 widzianych przez pryzmat czechosłowackich dzienników opiniotwórczych „Rudé právo” oraz „Mláda fronta”. „Rudé právo” było głównym organem prasowym Komitetu Centralnego Komunistycznej Partii Czechosłowacji; zostało założone w 1920 roku. Ogromnego znaczenia w Czechosłowacji nabrało po 1948 roku, kiedy to stało się dziennikiem o największym nakładzie w kraju - w 1989 roku wynosił on 1120000 egzemplarzy w dni powszednie i 1590000 dla wydania sobotniego ${ }^{4}$. „Mláda fronta” powstała w 1945 roku jako czasopismo skierowane do młodzieży; w roku 1970 stała się oficjalnym organem prasowym Komitetu Centralnego Socjalistycznego Związku Młodzieży. Był to trzeci najlepiej sprzedający się dziennik w Czechosłowacji, zaraz po „Rudym právie” i „Zemědělských novinách”. W 1989 roku nakład „Mládej fronty” wahał się w okolicach 325 tysięcy egzemplarzy 5 .

Główny problem badawczy, który został poruszony w prezentowanym artykule, można sprowadzić do pytania, w jaki sposób czechosłowacka prasa opiniotwórcza przedstawiała najważniejsze polskie wydarzenia polityczne roku 1989. Aby odpowiedzieć na to pytanie, należy zadać również inne - którym aspektom poświęcano najwięcej miejsca, a które $\mathrm{z}$ nich marginalizowano? W jakim stylu napisane zostały materiały dotyczące Polski? Czy był on specyficzny? Jeżeli tak, to dlaczego i jakie płyną z tego wnioski? Analizując teksty zamieszczone w omawianych tytułach prasowych, które w 1989 roku znajdowały się pod kontrolą czechosłowackich władz, można ustalić oficjalny stosunek, jaki rządzący Czechosłowacją mieli do spraw Polski. Inną, lecz równie istotną kwestią jest próba odtworzenia obrazu polskich wydarzeń kreowanych przez czechosłowacką władzę w świadomości swoich obywateli.

Wizerunek polskiej polityki w oficjalnej prasie czechosłowackiej w latach osiemdziesiątych XX wieku wpisuje się w problematykę badań nad oficjalnymi stosunkami między tymi dwoma państwami. To, w jaki sposób władze Czechosłowacji chciały informować swoich obywateli o polskiej polityce, w dużym stopniu odzwierciedla ich formalne stanowisko w tej kwestii. Tematyka oficjalnych stosunków polsko-czechosłowackich w latach osiemdziesiątych została już poruszona przez kilku badaczy ${ }^{6}$, wciąż jednak pozostaje jeszcze wiele niezbadanych zagadnień. Jednym $\mathrm{z}$ nich jest wizerunek polskich przemian politycznych roku 1989 w oficjalnej prasie Czechosłowacji.

szewski, Czechy i Słowacja, Warszawa 2008, s. 279-285; K. Pacner, Osudové okamžiky Československa, Praha 2018, s. 480-611.

${ }^{4}$ J. Petrů, Vývoj „Rudého práva” v období 1972-1991, Praha 2015, s. 51.

5 J. Končelík, P. Večeřa, P. Orság, Dějiny českých medií 20. století, Praha 2010, s. 253.

${ }^{6} \mathrm{Na}$ ten temat pisali między innymi: P. Blažek, Akce "Sever". Státní bezpečnost a krize Polské lidové republiky 1980-1984, Praha 2017; A. Szczepańska, Oficjalne relacje polsko-czechosłowackie w latach 1980-1989 w świetle raportów Ambasady PRL w Pradze, „Przegląd Zachodniopomorski” 2010, z. 4, s. 67-82; M. Świder, The political transformations in Poland after the Round Table in the light of materials sent in from Prague, [w:] P. Krákora et al., Obnova demokracie v Československu po roce 1989, Praha 2010, s. 252-268; A. Kobus, Czechosłowacja wobec narodzin, rozwoju i delegalizacji „Solidarności” (1980-1982), Toruń 2006. 


\section{Okrągły Stół}

Omawianie zagadnienia 1989 roku w Polsce w perspektywie czechosłowackiej prasy należy rozpocząć od jednodniowej wizyty Wojciecha Jaruzelskiego w Pradze, która miała miejsce 1 lutego. W jej trakcie I sekretarz Komitetu Centralnego PZPR rozmawiał ze swoim czechosłowackim „odpowiednikiem” — Milošem Jakešem — oraz z prezydentem Czechosłowacji Gustávem Husákiem. Jednym z głównych celów wizyty generała Jaruzelskiego w Pradze było oficjalne poinformowanie władz Czechosłowacji o sytuacji politycznej w Polsce, szczególnie o postanowieniach X Plenum KC PZPR oraz założeniach „planowanego porozumienia narodowego", czyli o taktyce przyjętej przed zbliżającymi się obradami Okrągłego Stołu. W czasie spotkania rozmawiano również o dalszej współpracy na polu politycznym, gospodarczym, kulturalnym, ekologicznym i turystyki indywidualnej. Przywódcy zapewnili się o dalszej współpracy ekonomicznej, w której oba państwa miały szukać nowych metod działalności w celu wytworzenia realnych obszarów integracji socjalistycznej ekonomiki ${ }^{7}$. Wizytę generała Jaruzelskiego w Pradze można interpretować jako próbę uspokojenia władz Czechosłowacji - przywódca PZPR zapewnił KPCz, iż sytuacja w Polsce jest pod kontrolą i czechosłowaccy towarzysze nie muszą obawiać się, że w PRL może dojść do nagłej zmiany dotychczasowego układu sił politycznych.

Rozmowy przy Okrągłym Stole rozpoczęly się 6 lutego. Pierwszy artykuł na ich temat ukazał się w „Rudym právie” następnego dnia. W ciągu kolejnych dwóch miesięcy, podczas których polska władza negocjowała $\mathrm{z}$ opozycją, dziennik ten opublikował w sumie około czterdziestu tekstów tematycznie nawiązujących do tego wydarzenia. Autorem większości z nich był korespondent „Rudego práva” z Warszawy - Pavol Minárik. O sytuacji w Polsce pisał także Dalibor Mácha. Obydwaj dziennikarze szczególnie podkreślali ekonomiczny aspekt negocjacji toczonych w Polsce. Prawie za każdym razem pod tekstem traktującym o samych rozmowach pojawiały się doniesienia na temat fatalnej sytuacji polskiej gospodarki i fali strajków towarzyszącej negocjacjom. Według Minárika głównym celem obrad Okrągłego Stołu było znalezienie rozwiązania dla problemów gospodarczych oraz poszukiwanie dalszych kierunków rozwoju państwa. Przyczyn złej sytuacji ekonomicznej dopatrywał się w „społecznej anarchii” z lat 1980-1981 oraz fali strajków z 1988 roku. Podkreślenie wagi aspektu gospodarczego znajdujemy między innymi w przytoczonych przez Minárika słowach premiera Mieczysława F. Rakowskiego, który miał powiedzieć, że nie jest przeciw Okrągłemu Stołowi, ale głównie starał się będzie o stół pełny ${ }^{8}$. Zapewne chodzi o sławną wypowiedź premiera, której udzielił podczas konferencji prasowej w październiku 1988 roku, a która w rzeczywistości brzmiała nieco inaczej ${ }^{9}$. Można odnieść wrażenie, że autorzy artykułów sugerowali, choć nie pisali o tym wprost, że polskie społeczeństwo z jednej strony doprowadziło do finansowych problemów Polski, a z drugiej jest bardzo niecierpliwe i chce natychmiastowej poprawy sytuacji gospodarczej.

\footnotetext{
7 D. Mácha, Čs. - polská jednání, „Rudé právo” 1989, nr 28, s. 1.

8 P. Minárik, V Polsku začaly rozhovory u kulatého stolu, „Rudé právo” 1989, nr 32, s. 7.

9 Wypowiedź M.F. Rakowskiego brzmiała: „Polaków mniej interesuje Okrągły Stół, bardziej zaś stół suto zastawiony" - zob. A. Dudek, Reglamentowana rewolucja..., s. 208.
} 
W tekstach Minárika i Máchy widać wyraźny kontrast między PZPR, która chciała wprowadzać skuteczne, stopniowe reformy, a stroną opozycyjną nastawioną na konfrontację i radykalne działania ${ }^{10}$. Do tego miały dochodzić tajemnicze „siły”, które nie brały udziału w negocjacjach. Ich temat został poruszony w artykule zatytułowanym Do czego dąża agresywne siły - czechosłowacki korespondent skupił się w nim na ciągłych strajkach, zamieszkach i antysowieckich prowokacjach w Polsce, których autorami miały być "grupy młodzieży”. Grupy te nie były zainteresowane toczonymi negocjacjami, a wręcz zależało im na naruszeniu ich przebiegu. Stały za nimi „konfrontacyjne siły”, które miały wykorzystywać łatwo podlegającą manipulacji młodzież ${ }^{11}$. Zapewne chodziło o ugrupowania opozycyjne, które nie brały udziału w obradach przy Okrągłym Stole, jak na przykład Konfederacja Polski Niepodległej ${ }^{12}$, jednak nie zostają one precyzyjnie wskazane przez autora.

Interesujący artykuł na temat Okrągłego Stołu ukazał się w „Rudym právie” 11 kwietnia. W języku polskim jego tytuł brzmi Krawędzie Okrągłego Stołu, podpisali się pod nim Dalibor Mácha i Pavol Minárik. W tekście, powołując się na słowa Leszka Millera, autorzy zwrócili uwagę, że spełnienie ustaleń przy Okrągłym Stole będzie wymagało dużych nakładów finansowych. Przy negocjacjach nikt jednak nie ustalał, skąd pozyskane zostaną te środki. Autorzy piszą o zaniepokojeniu członków PZPR, którzy bali się, że dalszy rozwój wydarzeń może doprowadzić do sytuacji z lat 1980-1981, kiedy rozpadła się gospodarka, a życiem społecznym rządziły „anarchia i strajkowy terroryzm”. Mácha i Minárik podali także, że dla władzy najważniejsze są reformy gospodarcze, które mają poprawić społeczną stopę życiową; za to opozycji, na czele z Lechem Wałęsą, bardziej zależy na reformach politycznych ${ }^{13}$. W tym momencie należy zdecydowanie podkreślić, że teksty publikowane $\mathrm{w}$ „Rudym právie” są głównie relacjami wypowiedzi polskich polityków lub analizami powtarzanymi za polskimi mediami; brakuje w nich komentarzy odautorskich. Dziennikarze woleli zachowywać ostrożność i niechętnie wydawali własne (czy nawet narzucone przez redakcję lub Komunistyczną Partię Czechosłowacji) sądy o sytuacji w Polsce. Ograniczali się do tego, co na ten temat oficjalnie mówiła polska władza oraz zależne od niej media.

Trochę inaczej sytuacja wygląda w wypadku „Mladej fronty”. W tym dzienniku informacje o bieżącej sytuacji w Polsce pojawiały się głównie w formie komentarzy zamieszczanych w dziale zagranicznym. Liczba informacji o przebiegu negocjacji przy Okrągłym Stole w porównaniu do „Rudego práva” była zdecydowanie mniejsza, jednak teksty na ten temat zawierały opinie ich autorów, a przez to stanowią ciekawsze i sprawiające mniej problemów źródło. Przykładowo w artykule opublikowanym w „Mladej froncie”

10 P. Minárik, Spory o tempo přeměn, „Rudé právo” 1989, nr 45, s. 7.

11 P. Minárik, Oč usilují agresívní síly, „Rudé právo” 1989, nr 52, s. 7.

12 Na temat KPN zob. B. Pobożny, Konfederacja Polski Niepodległej, na drodze do wolnych i demokratycznych wyborów, „Studia Politologiczne” 2011, nr 22, s. 216-241; M. Orski, Konfederacja Polski Niepodległej w latach 1979-1989, „Studia Rzeszowskie” 7, 2000, s. 59-87; A. Dudek, M. Gawlikowski, Leszek Moczulski - bez wahania, Kraków 1993.

13 D. Mácha, P. Minárik, Hrany kulatého stolu, „Rudé právo” 1989, nr 85, s. 7. 
14 lutego Jiři Vaško ${ }^{14} \mathrm{z}$ Warszawy pisał o różnicach między stronami zasiadającymi przy Okrągłym Stole. Według niego strona koalicyjna była za przejściem $\mathrm{z}$ „systemu autorytarnego" do „demokratycznego sprawowania władzy w społeczeństwie socjalistycznym”. Nazwał to „socjalistycznym odnowieniem kraju”. Opozycja zaś miała żądać przejścia od tego, co sama nazywała „totalnymi” i „monocentrycznymi” formami rządzenia, do „pluralistycznego społeczeństwa obywatelskiego”, a także „społeczeństwa demokracji parlamentarnej”. Autor stwierdził, że opozycja nie kryła się z tym, że nie chodzi jej o naprawę socjalizmu, ale o przejście z socjalistycznego rządzenia do rządzenia w zachodnim, burżuazyjnym typie. Uważał także, że żądania strony opozycyjnej nie różnią się za bardzo od postulatów z lat 1980-1981. Inna jest jedynie metoda ich realizacji — nie jest to już próba natychmiastowego wymuszenia pod naciskiem strajku, tylko droga ewolucyjna. Wyjątkiem jest żądanie legalizacji „Solidarności” — opozycja chciała natychmiastowej legalizacji tego związku zawodowego, który - według słów autora — „w latach 19801981 przywiódł Polskę do granicy wojny domowej, a który i dzisiaj ma być głównym kafarem w forsowaniu opozycyjnych projektów w kraju"15.

W innym artykule, który ukazał się na łamach „Mladej fronty” 1 marca, Ivo Bartík przypominał, że rokowania władzy z opozycją odbyły się w Polsce już dwukrotnie i za każdym razem nie prowadziły do żadnych pozytywnych wyników. Według niego pierwsze negocjacje miały mieć miejsce zaraz po II wojnie światowej, a drugie - na początku lat osiemdziesiątych. Autor wskazuje jednak, że w aktualnej sytuacji Okrągły Stół może okazać się niezbędny dla poprawy sytuacji w Polsce. Zarazem ostrzega, że same pertraktacje nie będą zbawieniem i nie można oczekiwać, aby wynikły z nich rozwiązania wszystkich krajowych problemów. Zwraca uwagę na dwa pozytywne skutki, które już wypłynęły z obrad Okrągłego Stołu: (1) opozycja wyszła ze swojego negatywnego podejścia do władzy, (2) wytworzona została atmosfera przed zbliżającymi się wyborami, w której opozycja może stać się współodpowiedzialna za sytuację w kraju ${ }^{16}$.

\section{Wybory czerwcowe}

Zainteresowanie czechosłowackich mediów toczonymi w Polsce negocjacjami władzy z opozycją nie ustało wraz z zakończeniem obrad przy Okrągłym Stole. Świadczy o tym czterogodzinna pogawędka telefoniczna Pavola Minárika z czytelnikami, którą redakcja „Rudego práva” postanowiła przeprowadzić 16 maja między godziną 14 a 18 . W jej trakcie czytelnicy mogli dzwonić do Minárika i zadawać mu pytania na temat Polski. Rezultat rozmowy opublikowano w numerze z 20 maja w artykule zatytułowanym Cztery godziny o Polsce. Z tej publikacji wynika kilka ciekawych stanowisk co do oficjalnego stosunku redakcji czasopisma do sytuacji w Polsce.

14 W 1989 roku Jiři Vaško był korespondentem Czechosłowackiej Agencji Prasowej (Česká Tisková Kancelář) w Warszawie; zob. M. Świder, op. cit., s. 254.

15 J. Vaško, Kompromis složitý, ale možný, „Mladá fronta” 1989, nr 38, s. 5. Wszystkie tłumaczenia D.M.

16 I. Bartík, Polské být, či nebýt, „Mladá fronta” 1989, nr 51, s. 5. 
W trakcie rozmowy Minárik stwierdził, że „konstruktywna opozycja”, czyli kompromisowo nastawione skrzydło „Solidarności”, zostanie dopuszczona do życia politycznego, aby nie tylko krytykować, lecz także wziąć na siebie część odpowiedzialności za sytuację w kraju. Opozycja ta dąży do zmiany systemu drogą ewolucji. Dziennikarz zauważył przy tym, że polska „Solidarność" na swoją kampanię wyborczą dostaje pomoc z Zachodu w postaci pieniędzy, techniki i ludzi. Był jednak zdania, że PZPR ma dużą szansę na zwycięstwo w czerwcowych wyborach. Uważał, że partia rządząca w Polsce nie musi wstydzić się przeszłości, a wraz z rozwiązywaniem kolejnych krajowych problemów będzie rosło jej społeczne poparcie. Stwierdził ponadto, że Wojciech Jaruzelski jest głównym kandydatem na prezydenta PRL. W połączeniu z zapewnieniem o popularności PZPR informacja ta mogła mieć na celu kształtowanie w umysłach czytelników obrazu sytuacji, w której to obóz władzy jest głównym rozgrywającym w toczącej się w Polsce grze politycznej. Na pytanie o to, czy zachodnie państwa pomogą Polakom uporać się z kłopotami gospodarczymi, Minárik odpowiedział, że jest to bardzo wątpliwe, ponieważ zachodnim politykom chodzi tylko o rozszerzenie sektora prywatnego w Polsce. To, co kraj ten osiągnął do tej pory, może zawdzięczać wyłącznie sobie oraz swoim sojusznikom, głównie Związkowi Radzieckiemu.

W kontekście stosunków Polski z państwami zachodnimi czechosłowacki korespondent uznał także, że papież Jan Paweł II miał wpływ na polepszenie relacji PRL z Włochami, ale raczej nie można tego powiedzieć o innych państwach kapitalistycznych. Zauważył też, iż w zbliżających się wyborach Kościół katolicki stoi po stronie opozycji i nie ma mowy o obiecywanej wcześniej neutralności.

W opublikowanym tekście widać także próbę „walki” z jednym z czeskich stereotypów na temat Polaków. Minárik stwierdził bowiem, że Polacy nie są narodem spekulantów. To, że wielu z nich handluje, jest skutkiem złej sytuacji gospodarczej ${ }^{17}$. Dziennikarz zauważył również, że sytuacja materialna polskiego robotnika jest o wiele gorsza niż czeskiego i słowackiego ${ }^{18}$.

W tekście opublikowano także pytanie i komentarz, które wiele mówią o stosunku „Rudego práva” do spraw polskich w omawianym okresie. Kilku czytelników interesowało bowiem, dlaczego dziennik przestał pisać „Solidarność” w cudzysłowie. Czy oznaczało to, że redakcja zmieniła stosunek do tego związku zawodowego? Minárik odpowiedział:

Przede wszystkim Solidarność jest dziś legalna. Nasi polscy sojusznicy w swoich analizach polityki wewnętrznej stwierdzili, że w kraju zmienił się charakter tej siły opozycyjnej, że w Solidarności jest wyraźne skrzydło. To oznacza, że można ją uznać za zwolennika konstruktywnej opozycji, która chce przystąpić do rozwiązywania nagromadzonych w kraju problemów. Jeżeli Solidarność te deklaracje spełni, będzie to

17 To wyjaśnienie mogło nie być przekonujące przy jednoczesnych doniesieniach „Rudégo práva” o Polakach, którzy byli odsyłani z granicy polsko-czechosłowackiej, ponieważ chcieli przewieźć do Czechosłowacji zbyt wiele towarów, którymi następnie zamierzali handlować; zob. Kulatý stůl před závěrem?, „Rudé právo" 1989 , nr 69, s. 7.

18 P. Minárik, Čtyři hodiny o Polsku, „Rudé právo” 1989, nr 117, s. 6. 
dowodem, że się zmieniła. Niestety, istnieją w jej władzach także radykalne siły, które myślą inaczej. Zatem - najlepiej odpowie czas $^{19}$.

Wspomniany wcześniej komentarz pochodził od Pawła Branny, który przedstawił się jako Polak mieszkający w Pradze. Według niego informacje podawane przez „Rudé právo” częściowo zniekształcały pogląd na Polskę. Minrik odpowiedział, że podobne zjawisko jest zupełnie normalne, a pismo przedstawia tylko najważniejsze wydarzenia, które zachodzą w sąsiednim państwie. Podobne wrażenie, ale w drugą stronę, odnoszą Czesi i Słowacy mieszkający w Warszawie, z którymi miał okazję rozmawiać. Dodał także:

Nie jesteśmy zainteresowani przedstawianiem sytuacji w Polsce w złowróżbny sposób. Gdy relacjonujemy wydarzenia $z$ Polski, chodzi nam przede wszystkim o obiektywny pogląd na to, jak wygląda polska sytuacja gospodarcza, jak żyje polski obywatel i jak polska władza i PZPR szukają rozwiązania wewnętrznych problemów kraju ${ }^{20}$.

Wyniki wyborów z 4 czerwca były dużym zaskoczeniem dla wszystkich, również dla Czechów i Słowaków. Tuż po ich ogłoszeniu „Rudé právo” upatrywało przyczyn porażki strony rządowo-koalicyjnej w rozdrobnieniu sił koalicji, w zbyt łagodnym podejściu do kampanii wyborczej (w porównaniu z agresywnym podejściem opozycji), a także w samym charakterze wyborów. Według tego, co pisali czechosłowaccy korespondenci, możliwość wolnego wyboru wyzwoliła społeczną frustrację nagromadzoną przez wiele lat. Do tego doszedł aktualny kryzys gospodarczy i konflikty na ulicach ${ }^{21}$. Należy też dodać, że wszystkie te tezy, jak poprzednio, nie są własnymi Minárika czy Máchy, lecz wynikają $\mathrm{z}$ analizy wypowiedzi sekretarza PZPR Mariana Orzechowskiego.

Na tym tle wyróżnia się szczególnie jeden artykuł opublikowany przez „Rudé právo”. Jest to tekst z 21 czerwca. Autorem ponownie był Minárik, jednak wymowa tej publikacji jest inna od poprzednich. Tytuł brzmi Naruszenie polskiej suwerenności. Dziennikarz nie powołuje się już na polskich polityków czy media, tylko sam (lub z czyjegoś polecenia) analizuje jedną z przyczyn wyników niedawnych wyborów, mianowicie ingerencję Zachodu w wewnętrzne sprawy Polski. $Z$ artykułu możemy dowiedzieć się między innymi, że pracownicy zachodnich ambasad w Warszawie pomagali kandydatom „Solidarności” jako doradcy i instruktorzy, a różne zachodnie organizacje, instytucje i związki przeznaczały na wsparcie polskiej opozycji znaczne środki ${ }^{22}$. Powołując się na „polskie dane”, dziennikarz stwierdził, że za granicą, głównie w USA i RFN od początku lat osiemdziesiątych powstało czterysta różnych centrali wspierających polską opozycję. Przez ten czas wysłały do Polski dziesiątki milionów dolarów, bez których aktywność opozycji byłaby prawie niemożliwa. W Polsce przed wyborami pojawiło się wielu za-

\section{Ibidem}

20 Ibidem.

21 P. Minárik, Př́činy porážky koalice, „Rudé právo” 1989, nr 133, s. 7.

22 Problematyka finansowania „Solidarności” przez instytucje zachodnie została już kilkakrotnie poruszona. Na ten temat zob. M. Świder, 1989 - rok przełomu i relacje polsko-niemieckie. Wsparcie SPD dla Komitetu Obywatelskiego „Solidarność, [w:] 25 lat polskiej transformacji systemowej - dokonania i wyzwania, red. J. Kornaś, Ł. Danel, Kraków 2014, s. 289-300; Solidarity with Solidarity: Western European Trade Unions and the Polish Crisis, 1980-1982, red. I. Goddeeris, Lanham 2013; B.B. Fischer, Solidarity, the CIA, and Western technology, „International Journal of Intelligence and Counter Intelligence” 2012, nr 25, s. 427-469. 
granicznych emisariuszy, którzy wspierali kampanię „Solidarności” — na przykład były doradca amerykańskiego prezydenta, Zbigniew Brzeziński²3. Według Minárika nie chodziło w tym o nic innego, jak o poważną ingerencję w polskie wybory.

Czechosłowacki korespondent powołał się także na słowa pewnego anonimowego przedstawiciela amerykańskiej władzy, który miał przyznać, że „Solidarność" dostaje rocznie pomoc w wysokości miliona dolarów. Minárik stwierdził, że nie była to pomoc dla związku zawodowego, tylko dla siły politycznej, która starała się zdobyć większość w organach prawodawczych państwa i swój cel osiągnęła. Opozycja dostawała z Zachodu również sprzęt poligraficzny i drukarski, a ponadto na jej potrzeby drukowano za granicą ulotki, plakaty i nalepki ${ }^{24}$. Dziennikarz zauważył też, że od władzy USA opozycja dostała do dyspozycji Radio Wolna Europa, które wykorzystywała głównie do oczerniania władzy ludowej. Pisał także o czasopiśmie „Kultura”, które według jego słów ukazywało się w Paryżu za pieniądze CIA i charakteryzowało się wyłącznie antypolską i antysocjalistyczną propagandą. Minárik skonstatował, że w latach 1980-1981 CIA uczestniczyła $w$ planach zlikwidowania socjalizmu w Polsce ${ }^{25}$. Według niego używała i nadal używa różnych, zarówno tajnych, jak i oficjalnych metod, w jednym celu: ,ingerowania w wewnętrzne sprawy PRL z zamiarem zburzenia jego społecznej struktury”. Autor tekstu napisał również, że CIA odegrała znamienną rolę w przeszłości, kiedy tworzyły się struktury polskiej opozycji. W połowie lat siedemdziesiątych miała zapewnić jej instrukcje, pieniądze, wsparcie polityczne i komunikację z zagranicą ${ }^{26}$. Dziennikarz postawił pytanie bez odpowiedzi: czy senatorowie i posłowie, którzy otrzymali pieniądze z Zachodu, są niezawiśli i mogą uczciwie reprezentować interesy swoich wyborców? Swój tekst podsumował w następujący sposób: „finansowe wsparcie z Zachodu dla »Solidarności« nie jest niczym innym niż poważnym naruszeniem polskiej suwerenności”27. „Mladá fronta” poświęciła wyborom czerwcowym zdecydowanie mniej miejsca niż „Rudé právo”. Przestała także komentować rozwój wydarzeń w Polsce, a zamiast tego publikowała relacje $\mathrm{z}$ wypowiedziami polskich polityków oraz teksty redakcyjne oparte na informacjach ukazujących się w polskich mediach ${ }^{28}$. W sumie na łamach „Mladej

23 Zbigniew Brzeziński (1928-2017) - politolog i sowietolog. Profesor na Uniwersytecie Columbia oraz Uniwersytecie Johna Hopkinsa w Baltimore. W latach 1977-1981 był doradcą prezydenta Jimmy’ego Cartera ds. bezpieczeństwa narodowego USA; zob. P. Vaughan, Zbigniew Brzeziński, przeł. P. Amsterdamski, J. Amsterdamska, J. Barczyński, Warszawa 2010.

24 Podkreślanie pomocy Zachodu dla „sił antysocjalistycznych” w Polsce sięga roku 1980. Na ten temat powstawały także analizy w Niemieckiej Republice Demokratycznej, zob. 1980 październik 9, Berlin - Pismo Ericha Mielkego dotyczace działań jednostek organizacyjnych MBP NRD zwiazanych $z$ sytuacja w PRL, tajne, [w:] Przed i po 13 grudnia. Państwa bloku wschodniego wobec kryzysu w PRL 1980-1982, oprac. Ł. Kamiński, t. 1, Warszawa 2006, s. 102-108.

${ }^{25} \mathrm{Na}$ temat roli, jaką CIA odegrała podczas polskiego kryzysu politycznego z lat 1980-1981, zob. R.T. Davies, The CIA and the Polish crisis of 1980-1981, „Journal of Cold War Studies” 6, 2004, s. 120-123.

26 P. Minárik, Porušování polské svrchovanosti, „Rudé právo” 1989, nr 144, s. 7.

27 Ibidem.

28 Velká zkouška reforem a dialogu, „Mladá frontá” 1989, nr 130, s. 3; Stále hrozí slepá ulička, „Mladá fronta" 1989, nr 141, s. 5. 
fronty" ukazało się zaledwie kilka artykułów na temat wyborów z 4 czerwca, a większość $\mathrm{z}$ nich poświęcona była niskiej frekwencji w drugiej turze głosowania ${ }^{29}$.

Kolejne wydarzenia, które miały miejsce w Polsce, nie dostawały już tak wiele miejsca na łamach omawianych dzienników. Przykładem może być wybór generała Jaruzelskiego na prezydenta. „Rudé právo” i „Mladá fronta” widziały w tym szansę na zachowanie rozwagi w polskiej polityce, niedopuszczenie do anarchii i utrzymanie gospodarki socjalistycznej ${ }^{30}$. Gdy Tadeusz Mazowiecki został premierem i nie spotkał się z krytyką mediów rządowych, widziały w nim raczej osobę, która może zadziałać uspokajająco na społeczne nastroje ${ }^{31}$.

Koniec roku 1989 w Czechosłowacji był bardzo gorący. W listopadzie rozpoczęła się aksamitna rewolucja i w ciągu dwóch następnych miesięcy stosunki polityczne w kraju zupełnie się zmieniły. Ta gorąca atmosfera mogła być głównym powodem, dla którego wyraźnie spadło zainteresowanie dla ówczesnych zajść w Polsce. Wyjątek stanowi mała notatka zamieszczona w „Mladej froncie”, w pierwszym numerze z 1990 roku, na temat zmiany nazwy państwa na Rzeczpospolita Polska ${ }^{32}$ oraz jedna karykatura i cytat Lecha Wałęsy zamieszczone $\mathrm{w}$ „Rudym právie”33 pod koniec grudnia.

\section{Podsumowanie}

Podsumowując analizę przekazów „Rudego práva” i „Mladej fronty” na temat polskiej transformacji systemowej z 1989 roku, można wysnuć kilka interesujących wniosków. Przede wszystkim wyraźnie widać, że najpotężniejszy dziennik w Czechosłowacji, czyli „Rudé právo", starał się zachowywać ostrożność w opisywaniu polskich wydarzeń. Autorem zdecydowanej większości tekstów publikowanych na jego łamach był warszawski korespondent Pavol Minárik, który zwykle przytaczał komentarze polskich mediów i wypowiedzi polityków. Podkreślał przy tym polskie problemy gospodarcze i ich wpływ na niezadowolenie społeczne. Opisywana przez niego opozycja, która przystąpiła do negocjacji z władzą, została potraktowana jako zło konieczne - mniejsze od innych, bardziej radykalnych i podżegających do niepokojów społecznych sił, które także obecne są w Polsce.

Sytuacja podobnie wyglądała na łamach „Mladej fronty”. Dziennik ten, skierowany do młodzieży, zdecydowanie rzadziej publikował materiały na temat sytuacji w Polsce, jednak częściej przybierały one formę komentarzy. „Mladá fronta” nie podejmowała prób krytyki polskiej polityki wewnętrznej. Negatywne oceny zarezerwowane były dla

29 Ještě méně voličư?, „Mladá fronta” 1989, nr 142, s. 4; Přišla jen čtvrtina, „Mladá fronta” 1989, nr 143, s. 5.

30 P. Minárik, Wojciech Jaruzelski prezidentem, „Rudé právo” 1989, nr 169, s. 1, 7; I. Bartík, Volba dává naději, „Mláda frontá” 1989, nr 171, s. 5.

31 P. Minárik, Nový premiér, nová vláda, „Rudé Právo” 1989, nr 200, s. 7; Nový premiér v Polsku, „Mláda frontá” 1989, nr 200, s. 1, 5; M. Komarek, Hlavní problém: hospodářství, „Mláda frontá” 1989, nr 201, s. 5.

32 Polská republika, „Mladá fronta” 1990, nr 1, s. 3.

33 Cytat brzmiał: „Nie macie pojęcia, jak dramatyczna jest nasza sytuacja. Jeżeli będzie tak dalej, to przyjdą niezadowoleni i podpalą mi dom" i został opublikowany pod tytułem Kto będzie gasić; zob. Kdo bude hasit?, „Rudé právo” 1989, nr 307, s. 6. 
„Solidarności”, chociaż podkreślano, że nie jest to już ta sama „Solidarność, która pamiętano z lat 1980-1981.

Można zapytać: dlaczego czechosłowacka prasa nie prezentowała własnego zdania na temat sytuacji w Polsce? Najprawdopodobniej ma to związek z tym, że wówczas nikt nie wiedział, jak potoczą się dalsze wydarzenia. Związek Radziecki nie ingerował głównie ze względu na własne problemy wewnętrzne oraz na potrzebę poprawy relacji z Zachodem ${ }^{34}$. Wszelka krytyka pochodząca ze ZSRR miałaby swoje odbicie w czechosłowackiej prasie, ale jej tam nie było. Władza w tym państwie uważnie obserwowała polskie wydarzenia, a jej oficjalne zdanie na ich temat pokrywało się ze zdaniem PZPR. Wszyscy czekali, obserwując, jak rozwinie się sytuacja w Polsce. Wyraźnie to widać po sposobie opisywania wydarzeń na łamach „Rudego práva” i „Mladej fronty”. Mimo tego podkreślanie złej sytuacji gospodarczej w PRL mogło mieć na celu zmniejszenie sympatii lepiej zaopatrzonych w dobra materialne Czechów i Słowaków do przemian zachodzących w Polsce.

\section{Bibliografia}

Bankowicz M., Zlikwidowane państwo. Ze studiów nad polityką Czechosłowacji, Wydawnictwo Uniwersytetu Jagiellońskiego, Kraków 2003.

Blažek P., Akce „Sever”. Státní bezpečnost a krize Polské lidové republiky 1980-1984, Ústav pro studium totalitních režimü, Praha 2017.

Burakowski A., Gubrynowicz A., Ukielski P., 1989 — Jesień Narodów, TRIO, Warszawa 2009.

Davies R.T., The CIA and the Polish crisis of 1980-1981, „Journal of Cold War Studies” 6, 2004 s. 120-123.

Dobbs M., Precz z Wielkim Bratem. Upadek Imperium Radzieckiego, przeł. P. Kwiatkowski, Rebis, Poznań 1998.

Dudek A., Historia polityczna Polski 1989-2005, Arcana, Kraków 2007.

Dudek A., Reglamentowana rewolucja: rozkład dyktatury komunistycznej w Polsce 1988-1990, Arcana, Kraków 2004.

Dudek A., Gawlikowski M., Leszek Moczulski - bez wahania, Krakowski Instytut Wydawniczy, Kraków 1993.

Fischer B.B., Solidarity, the CIA, and Western technology, „International Journal of Intelligence and Counter Intelligence" 2012, nr 25, s. 427-469.

Kobus A., Czechosłowacja wobec narodzin, rozwoju i delegalizacji „Solidarności” (1980-1982), Wydawnictwo Adam Marszałek, Toruń 2006.

Kopeček P., Rok 1989 ve střední Evropě (Polsko, Mad'arsko, NDR, Československo), [w:] Obnova demokracie v Československu po roce 1989, red. P. Krákora, Epocha, Praha 2010.

Končelík J., Večeřa P., Orság P., Dějiny českých medií 20. století, Portál, Praha 2010, s. 218-225.

Kotkin S., Armagedon był o krok. Rozpad Związku Radzieckiego 1970-2000, przeł. M. Szubert, Świat Książki, Warszawa 2009.

Marples D.R., Historia ZSRR. Od rewolucji do rozpadu, przeł. I. Scharoch, Zakład Narodowy im. Ossolińskich, Wrocław 2006.

„Mladá fronta” 1989.

Orski M., Konfederacja Polski Niepodległej w latach 1979-1989, „Studia Rzeszowskie” 7, 2000, s. 59-87.

Pacner K., Osudové okamžiky Československa, Plus, Praha 2018, https://is.cuni.cz/webapps/zzp/detail/139184.

34 P. Kopeček, op. cit., s. 218-219; S. Kotkin, Armagedon był o krok. Rozpad Związku Radzieckiego 19702000, przeł. M. Szubert, Warszawa 2009, s. 97; D.R. Marples, Historia ZSRR. Od rewolucji do rozpadu, przeł. I. Scharoch, Wrocław 2006, s. 307-312; M. Dobbs, Precz z Wielkim Bratem. Upadek Imperium Radzieckiego, przeł. P. Kwiatkowski, Poznań 1998, s. 317. 
Paczkowski A., Od sfałszowanego zwycięstwa do prawdziwej klęski. Szkice do portretu PRL, Wydawnictwo Literackie, Kraków 1999.

Petrů J., Vývoj „Rudého práva” v období 1972-1991, Praha 2015, https://is.cuni.cz/webapps/zzp/detail/139184.

Pobożny B., Konfederacja Polski Niepodległej, na drodze do wolnych i demokratycznych wyborów, „Studia Politologiczne" 2011, nr 22 s. 216-241.

Przed i po 13 grudnia. Państwa bloku wschodniego wobec kryzysu w PRL 1980-1982, oprac. Ł. Kamiński, t. 1, IPN, Warszawa 2006.

„Rudé právo" 1989.

Skórzyński J., Okrągly Stót. Wynegocjowany koniec PRL, Znak, Kraków 2019.

Solidarity with Solidarity: Western European Trade Unions and the Polish Crisis, 1980-1982, red. I. Goddeeris, Rowman \& Littlefield Publishing Group, Lanham 2013.

Sowa A.L., Historia polityczna Polski 1944-1991, Wydawnictwo Literackie, Kraków 2011.

Szczepańska A., Oficjalne relacje polsko-czechosłowackie w latach 1980-1989 w świetle raportów Ambasady PRL w Pradze, „Przegląd Zachodniopomorski” 2010, z. 4, s. 67-82.

Świder M., 1989 - rok przełomu i relacje polsko-niemieckie. Wsparcie SPD dla Komitetu Obywatelskiego „Solidarność", [w:] 25 lat polskiej transformacji systemowej - dokonania i wyzwania, red. J. Karnaś, Ł. Daniela, AGH, Kraków 2014.

Świder M., The political transformations in Poland after the Round Table in the light of materials sent in from Prague, [w:] Obnova demokracie v Československu po roce 1989, red. P. Krákora, Epocha, Praha 2010, s. 252-268.

Tomaszewski J., Czechy i Słowacja, TRIO, Warszawa 2008.

Trembicka K., Okragly Stół w Polsce. Studium o porozumieniu politycznym, Wydawnictwo Uniwersytetu Marii Curie-Skłodowskiej, Lublin 2003.

Vaughan P., Zbigniew Brzeziński, przeł. P. Amsterdamski, J. Amsterdamska, J. Barczyński, Świat Książki, Warszawa 2010.

\title{
The Polish year 1989 through the perspective of Czechoslovak opinion-forming daily press
}

\author{
Keywords: Czechoslovakia, Polish-Czechoslovak relations, 1989, Rudé právo, Mladá fronta
}

\section{Summary}

The main goal of this article is to show the image of the most important Polish political actions in 1989 through the prism of Czechoslovak opinion-forming daily press: Rudé právo and Mladá fronta. The author is focused on the analysis of materials generally connected with the deliberations of the Round Table, as well as the Polish legislative election on 4 June. It is desirable to disclose the way of presenting of the most important actions in Poland by the Czechoslovak press in that period, which we have mentioned above. The author also tries to determine how acute was the attention of the press to the Polish events that had taken place during those times. The newspapers, that are analysed, were controlled by Czechoslovak Rule and they were medium of its current views. According to this fact we could emphasize one of the elements in the sphere of the official relations between Poland and Czechoslovakia in relation in the year 1989. We could also reconstruct the Polish situational image which was presented to Czechoslovak citizens by the Czechoslovak authorities. 